\title{
A STUDY OF PROPER PRONUNCIATION AS A FACTOR OF SUCCESSFUL COMMUNICATION
}

\author{
Vesna Prodanovska-Poposka ${ }^{1}$
}

\begin{abstract}
Speaking as a productive skill is one of the very first obstacles that foreign language users face when using the language. Knowledge of a language does not refer to the correct and proper pronunciation however, being able to produce sounds, words or utterances in their proper way does not refer to proficiency of a language nor can it assess the overall level of the user of that particular language. The aim of this study is to present the components of speaking as a productive skill emphasizing the role of acquiring proper pronunciation as a factor for effective communication. The study also presents the most significant "common core" of English pronunciation as a lingua franca, details of the requested phonological competence as knowledge set by the Common European Framework of Languages: Learning, Teaching and Assessment and viewpoints of EFL teachers and authors. Additionally, the study includes data from EFL self- assessments from University students in Macedonia regarding their speaking and pronunciation skills and overall evaluation from their assessor -an English language instructor.
\end{abstract}

UDC Classification: 8, 81, 81-13; DOI: http://dx.doi.org/10.12955/cbup.v5.1024

Keywords: Speaking, Proper Pronunciation, Communication, EFL

\section{Introduction}

Speaking as a productive skill is one of the very first matters that foreign language users face when using the new language. Knowledge of a language does not refer to pronouncing it correctly and properly however, being able to produce sounds, words or utterances in their proper way does not refer to proficiency nor can it assess the overall level of the user of that particular language. Speaking a language well and intelligibly regardless of the situation a language user can be found in, appears to be the utmost demand and desire among learners and users of a foreign language. Pronunciation is an inevitable part of speaking skills, and inadequate pronunciation skills can have serious negative effects on the speakers such as lack of self-confidence to speak up, restraining from speaking in front of a group and not participating in social interactions.

\section{Language and speech utterance}

According to Stefanova (1999: 89) in real life the aim of speaking is to reach an understanding between two or more partners in a given situation. Yet in SLA the mother tongue is used as a means to explain new concepts in the target language. This applies however, only if the learner and the teacher speak the same native language. While in a situation where the language is foreign to both (teacher and student), then this target language becomes the only means of communication for the teacher and for learner. In the analysis of SLA, it is established that speaking is one of the four language skills which is considered as one of the most used types of language learning activity.

However, which participant involved in the learning process (teacher and student) speaks more is another matter and it is expected that the students should be more active in speaking in order to develop the communication skills in certain situations. In a normal communication between two or more interlocutors everyone involved is dealing with both, speaking and listening.

In the analysis of speaking skill among students Stefanova (1999) states that "very often, especially at the beginning of the learning process, the learners make pseudo-communication, i.e. they speak, but in reality there is no exchange of information, but only the reproduced speech of the teacher or recording. To this kind of talk we can encounter reading out loud as well, which is defined as persistent" (p. 89).

In order to make the formation of speech utterance one must pass through several psychological units, namely Stefanova, (1999) lists the following:

"Motive for speech utterance

This refers to the need to intervene i.e. sharing certain information or own thought. In cases of dialogue, the willingness to respond to the statement of the other party can serve as a motive for speaking.

Concept of speech utterance

\footnotetext{
${ }^{1}$ Faculty of Biotechnical Sciences, St. Kliment Ohridski University- Bitola, R. Macedonia, vesna.prodanovska@uklo.edu.mk
} 
This is the outcome which determines the content. The participant is in a process of transformation of the subjective sense of linguistic meanings that are understandable to the other participants in the conversation.

Forming speech utterance

This process is composed of three parts namely:

- Primary semantic recording (this is an incomplete statement which is further converted into the full form or sentence of words associated with one another)

- Inner speech (this is the second stage of formation of speech utterance)

- Sprawled speech utterance (this is the last stage when the inner meaning becomes the thoughts in built form i.e. the transmission of information from one person to another, which as a whole statement becomes a system with qualities of a closed structure)" (p.90).

\section{The aim of teaching speaking}

The aim of teaching speaking is acquiring suitable reactions according to a conversational situation or sphere in direct or indirect contact. Stefanova (1999) brings these teaching targets regarding the speaking:

"-acquiring correct pronunciation

-acquiring lexical units necessary to make the speech intentions in a particular speech situation

-Correct usage of the necessary language tools for the realization of speech intentions" (p.91).

The aim of acquiring proper and understandable pronunciation does not mean that students will have to sound as native speakers of the language they learn. This can occur in exceptional cases among some very talented and motivated students but it is an unrealistic goal. As to that, a realistic goal regarding teaching and acquiring foreign language is to enable students to "escape" the threshold level so their pronunciation does not distract them from their ability to communicate. Having established the level of understandable/acceptable pronunciation, which is one of the necessary components for successful communication, the next question is which additional methodological tools should language teachers use in order to improve the pronunciation of "incomprehensible" speakers of English, so that they would become "understandable" or "acceptable" speakers? However, this is an issue of communicative language teaching, as proponents of this approach have not expressed adequately regarding learning pronunciation in language teaching, nor have developed a range of strategies for teaching pronunciation through communication.

\section{Core Elements of Proper Pronunciation}

As for the approaches to the pronunciation of English as a language of international communication, Jennifer Jenkins defines the "common core" of English pronunciation as a lingua franca and identifies four main characteristics (Shopov, 2013, p. 309):

- Inventory of consonants. All consonants are important except for the sounds 'th' (as in thin and this)

- Consonant clusters at the beginning and middle of a word are important. For example, 'string' cannot be reduced to 'sting' or 'tring'

- Quantitative sign of vowels: the contrast between long and short vowels is important

- Nuclear stress which is the stress on the most important word or syllable is important.

According to Stefanova (1999) pronunciation is one of the main prerequisites for successful speech communication and to achieve it the learners need to build habits of pronunciation themselves, i.e. they need to learn to pronounce the foreign sounds, especially those that are difficult and different from their native language" (p.92).

According to Dalton and Seidlhofer (1994), there are two options to feature the pronunciation as production of meaningful sounds:

"First, sound is significant because it is used as part of a code of a particular language. So, we can talk about the distinctive sounds of English, French, Thai, and other languages. In this sense, we can talk about pronunciation as the production and reception of sounds of speech. 
Second, sound is significant because it is used to achieve meaning in context of use. Here the code combines with other factors to make communication possible. In this sense we can talk about pronunciation with reference to acts of speaking" (p. 3).

There are two main features of pronunciation - segmental and suprasegmental. Segmental features are actually sounds units of a language- phonemes which are divided into two main categories such as vowels, subdivided into monophthongs and diphthongs (and according to some authors and theories thriphthongs) and consonants, which generally are divided into voiced and voiceless. Suprasegmental refer to the more complex language features, such as intonation and stress namely a bit more of the phonological properties aside from characterizing the sounds as vowels and consonants. Acquiring proper pronunciation comprises competence in both, segmental and suprasegmental features.

\section{Abilities and Capabilities of Speakers of English as a Foreign Language}

As stated in the Common European Framework of Languages: Learning, Teaching and Assessment (2001) "Phonological competence involves knowledge of and skills in perception and production of:

- the sound-units (phonemes) of the language and their realization in particular contexts (allophones

- the phonetic features which distinguish phonemes (distinctive features, e.g. voicing, rounding, nasality, plosion);

- the phonetic composition of words (syllable structure, the sequence of phonemes, word stress, word tones);

- sentence phonetics (prosody)

- sentence stress and rhythm

- intonation;

- phonetic reduction

- vowel reduction

- strong and weak forms

- assimilation

- elision" (p.116-117)

Or as described below, acquiring a phonological competence the speakers (referring to the CEFR levels) need to have the abilities as presented in the chart as follows:

\begin{tabular}{l|l}
\hline & PHONOLOGICAL CONTROL \\
\hline C2 & \multicolumn{1}{c}{ As C1 } \\
\hline C1 & Can vary intonation and place sentence stress correctly in order to express finer shades of meaning. \\
\hline B2 & Has acquired a clear, natural, pronunciation and intonation. \\
\hline B1 & $\begin{array}{l}\text { Pronunciation is clearly intelligible even if a foreign accent is sometimes evident and occasional } \\
\text { mispronunciations occur. }\end{array}$ \\
\hline A2 & $\begin{array}{l}\text { Pronunciation is generally clear enough to be understood despite a noticeable foreign accent, but } \\
\text { conversational partners will need to ask for repetition from time to time. }\end{array}$ \\
\hline A1 & $\begin{array}{l}\text { Pronunciation of a very limited repertoire of learnt words and phrases can be understood with some } \\
\text { effort by native speakers used to dealing with speakers of his/her language group. }\end{array}$ \\
\hline
\end{tabular}

Source: Common European Framework of Reference for Languages: Learning, Teaching, Assessment, page 117

\section{The Importance of Proper Pronunciation}

Since speaking is the basic element when communicating, pronunciation inevitably is seen and discussed by many authors and teachers that have come across it. EFL learners face speaking as a mere difficulty in acquiring the desired level and often it is depending on the level of pronunciation. 
Even though the overall level of EFL learner can appear as high yet the pronunciation can seriously affect the communication when using the acquired language.

Tench (1981) claims that "Pronunciation is not an optional extra for the language learner, any more than grammar, vocabulary or any other aspect of language is. If a learner's general aim is to talk intelligibly to others in another language, a reasonable pronunciation is important" (p.1)

Wong (1987) indicates that even when the non-native speakers' vocabulary and grammar are excellent, if their pronunciation falls below a certain threshold level they are unable to communicate efficiently and effectively.

According to Gilakjani (2012) "learners with good English pronunciation are likely to be understood even if they make errors in other areas, whereas learners with bad pronunciation will not be understood, even if their grammar is perfect. Such learners may avoid speaking in English, and experience social isolation, employment difficulties and limited opportunities for further study. We judge people by the way they speak, and so learners with poor pronunciation may be judged as incompetent, uneducated or lacking in knowledge. Yet many learners find pronunciation one of the most difficult aspects of English to acquire, and need explicit help from the teacher. Therefore, some sort of pronunciation instruction in class is necessary" (1).

Pronunciation is the initial and key aspect in the development of speaking skills. As Burns (2003) points out "... regardless of small inaccuracies in vocabulary and grammar students are more likely to communicate effectively when they have good pronunciation and intonation" (p.5) Nowadays it is not a trend for the learners to express themselves and sound like in their mother tongue. In fact, according to Moyer (2004) and Scovel (2000) (as cited in Kang 2010) "... adult L2 learners rarely achieve nativelike speech patterns (Moyer, 2004; Scovel, 2000), and native-like pronunciation among those who acquire an L2 after early childhood is difficult to achieve in typical ESL classrooms" (p.106).

As Ur (1996) observes, "...the aim of pronunciation improvement is not to achieve a perfect imitation of a native accent, but simply to get the learner to pronounce accurately enough to be easily and comfortably comprehensible to other (competent) speakers " (p.52). According to Burns (2003) "... far more important for the speakers to be able to achieve the minimum level of understandability intelligibility (acoustic models produced by the speaker to be recognizable as English) acceptable comprehensibility (listener can understand the meaning of what is said) and high intelligibility interpretability (listener can understand the purpose of what is said)" (p.5)

\section{Self-assessment of EFL university students in Macedonia}

In order to support the necessity of acquiring competence in pronunciation the author presents a more thorough view regarding the pronunciation level and difficulties when lacking those skills in communication, through interviews (conducted voluntarily) among two EFL university students. The interviews are a segment of the author's $\mathrm{PhD}$ thesis research. The interview was conducted on two separate groups of students:

The first group- learners of English for a Specific Purposes- Business English, The second group - students majoring in the English language.

As for the research, the target groups include students with different majors - Business and Logistics vs. English Philology, from Gotse Delchev University in Shtip, R. Macedonia. Both groups consisted of 119 participants fulfilling the prerequisites for the research- B1 level for both groups and successful completion of:

- the first semester of all English courses (including English Phonetics) for English language students, and

- the successful completion of two semesters and passed ESP (Business English course) exam for group participants of Business and Logistics.

The aim of the research was set according to the personal opinion of the students to determine their current condition in terms of speaking and pronunciation issues when using the English language.

The interview was done to both groups separately while the students were sharing their own opinions through answering questions in which they were required to debate on topics outside the curriculum, such as their own vision for the future, favourite books or movies, the reason they choose their major, and finally how they see their own skills in English so far. The answers were given voluntarily, in 
order to create an informal and stimulating environment and avoid feelings of anxiety such as being questioned or sitting an exam. For the same reason the author avoided audio or video recordings, including only discrete recording of the most interesting answers and marking the mistakes in pronunciation.

In the interview students majoring in English language and Literature claim they have a hard time when communicating with foreigners at a higher level, in particular with the native speakers. They noticed that except that sometimes the meaning of what was said by the other speaker is lost, they are not being understood correctly in certain situations, especially when trying to explain issues that were almost directly translated from their native language into English. They also pointed out that some English words that are not correctly pronounced lead to ambiguity especially if not paying enough attention for example with the phoneme [th], which is most often mixed with [t, d] or [s, z], improper use of vowels etc.

In the interview, the students majoring in Business and Logistics claim that they sometimes find it difficult to communicate with native speakers or English-speaking person at a higher level than theirs. They feel relieved and more relaxed if they are able to communicate with people at a lower level of English, i.e. alike their level. Similarly to the other group, this group of students claims that sometimes they lose the meaning of what was said by the other speaker, being not understood properly, especially when trying to explain issues that were almost directly translated from their native language in English. In order to explain themselves students use a variety of ways, including hands and gestures. Special attention was paid to the answers regarding how they assess their own skills in English, the ability to speak etc. in which most of them shared that they experience serious difficulties when trying to use the language orally.

As with the interview the author was able to make generalizations and conclusions about the attitude of students to their problems while speaking English and using the correct pronunciation, such as:

- All students more or less are not quite comfortable speaking English because they are afraid of making mistakes. This usually occurs at the level of beginners, but sometimes it is noticed with students of higher level. Most of them act as if they are afraid to be criticized by teachers and other students.

- A problem also arises when students claim that they do not have sufficient information on a topic that is being discussed during the course of a debate. They do not feel able to follow and participate the discussion, miss out the idea to think or to work on their pronunciation and miss out the correct manner or using particular feature of the spoken language, such as proper pronunciation of [th], vowels in their long form etc.

\section{Conclusion}

As of the aforementioned, mastering the correct pronunciation is an important sub-objective in the development of speech skills. As widely aware of the pronunciation as a mandatory skill for English language speakers, one should bear in mind that acquiring correct pronunciation would affect the level of fluency (which can be frustrating if opposite), it could impede future success regarding jobs, education etc., and as the most significant matter if the learner masters the pronunciation initially the sooner he/ she would reach fluency. Studies in the field of English as a second language have found that the minimum intelligibility, acceptable comprehensibility and neutral accent can help achieve good oral communication. Once a fluent dialog is established, effective communication is established as well.

\section{References}

Burns, A. (2003). Clearly speaking: pronunciation in action for teachers. National Center for English Language Teaching and Research, Macquaire Universaity, Sydney NSW 2109, 5

Council of Europe. (2001). Common European framework of reference for languages: Learning, teaching, assessment. Cambridge, U.K: Press Syndicate of the University of Cambridge. 116-117

Dalton, C. \& B. Seidlhofer. (1994). Pronunciation. Oxford: Oxford University Press. 3

Kang, O. (2010). ESL learners' attitudes toward pronunciation instruction and varieties of English. In J. Levis \& K. LeVelle (eds.), Proceedings of the 1st Pronunciation in Second Language Learning and Teaching Conference. Ames, IA: Iowa State University, 105-118

Pourhosein Gilakjani, A. P. (2012). The Significance of Pronunciation in English Language Teaching. English Language Teaching, 5(4). doi:10.5539/elt.v5n4p96. 1 
Shopov, T. (2013) Педагогика на езика. Наръчник по комуникативно преподаване и учене на английски език. [Pedagogika na ezika. Narŭchnik po komunikativno prepodavane i uchene na anglǐ̌ski ezik. ] София: Университетско издателство, Св. Климент Охридски“. 309

Stefanova, Р. (1999). Методика на чуждоезиково обучение. [Metodika na chuzhdoezikovo obuchenie ].София. Издаделство „Парадигма“. 89-92

Tench, P. (1981) Pronunciation Skills (Essential Language Teaching Series). Macmillan Education Ltd. 1

Ur, P. (1996). A Course in Language Teaching: Practice and Theory. Cambridge University Press. ISBN 987-0-521-44994-6 Paperback, 52

Wong, R. (1987). Teaching Pronunciation: Focus on English Rhythm and Intonation. Englewood Cliffs, NJ: Prentice Hall Regents. 